\title{
PENGARUH PELAPUKAN TERHADAP KADAR PLATINA DAN PALADIUM NIKEL LATERIT KONAWE UTARA
}

\section{Effect of Weathering on Platinum and Palladium Compositions in Two Ni-laterites of North Konawe}

\author{
RONALDO IRZON ${ }^{1,2}$, KURNIA ${ }^{1}$, PURNAMA SENDJAJA ${ }^{1}$, DIAN HARISAPUTRA ${ }^{1}$, dan \\ BAHARUDDIN ${ }^{1}$ \\ 1 Pusat Survei Geologi \\ Jl. Diponegoro 57 Bandung \\ e-mail : ronaldoirzon18@gmail.com \\ ${ }^{2}$ Fakultas Teknik Geologi, Universitas Padjadjaran \\ Jl. Raya Bandung Sumedang KM 21, Jatinangor \\ e-mail: ronaldo17003@mail.unpad.ac.id
}

\begin{abstract}
ABSTRAK
Platinum Group Element (PGE) merupakan logam transisi dengan kelimpahan sangat rendah yang terdiri dari platina (Pt), paladium (Pd), rodium (Rh), osmium $(\mathrm{Os})$, dan rutenium $(\mathrm{Ru})$. Selain terkait dengan sulfida, kelompok logam ini bersifat siderofil (mudah larut dalam besi) dan kalkofil (mudah bercampur dengan belerang). Proses pelapukan batuan menghasilkan beberapa lapisan sejajar permukaan tanah namun dengan kenampakan megaskopis berbeda dan disebut sebagai horizon. Studi mengenai PGE cukup banyak dilaksanakan pada wilayah batuan ultramafik dan lapukannya. Tingkat pelapukan dapat dihitung menggunakan beberapa formula berdasarkan komposisi geokimianya. Studi ini bertujuan untuk mengetahui perubahan kadar Pt dan Pd pada pelapukan batuan ultramafik Andowia dan Asera yang merupakan bagian dari Kabupaten Konawe Utara. Chemical index of alteration (CIA) dan chemical index of alteration without potash (CIA-K) adalah dua jenis indeks pelapukan berbasis geokimia yang dikalkulasi untuk mengetahui korelasinya terhadap komposisi PGE masing-masing horizon. Pengukuran Pt dan Pd dilaksanakan menggunakan perangkat ICP-MS setelah tahap prakonsentrasi dengan teknik uji kadar logam (fire assay). Hasil analisis menunjukkan bahwa Pt dan Pd tertinggi terdapat pada horizon yang berada tepat di bawah lapisan tanah bagian atas (top soil) yang diduga terkait dengan komposisi Fe dan S pada setiap horizon di kedua profil studi. Indeks $\mathrm{ClA}$ dan $\mathrm{ClA}-\mathrm{K}$ di sini sangat mirip akibat kandungan oksida kalium yang sangat rendah pada setiap percontoh. Indeks pelapukan berbanding lurus dengan kelimpahan Pt dan Pd pada setiap profil dengan korelasi sangat kuat. Perubahan CIA dan ClA-K yang drastis pada salah satu horizon di Asera menunjukkan bahwa pelapukan di sini ini telah terganggu oleh endapan lepas dari tempat lain. Pada sisi lain, pelapukan berjalan normal di Andowia berdasarkan pada kenaikan teratur $\mathrm{CIA}$ dan $\mathrm{CIA}-\mathrm{K}$ dari horizon paling bawah menuju ke atas.
\end{abstract}

Kata kunci: indeks pelapukan, platina-paladium, pelapukan, ultramafik

\begin{abstract}
Platinum Group Element is a transition metal with a very low abundance that consists of platinum, palladium, rhodium, osmium, and ruthenium. The siderophile and chalcophile metals are also associated with sulfides. The weathering process produces several layers that are parallel to the soil surface but with different megascopic appearance called the horizon. Many studies on PGE were conducted in areas with ultramafic rocks and the
\end{abstract}


results of weathering. The weathering levels can be calculated using several formulas based on geochemical composition. This study aims to understand the Pt and Pd composition change in the two weathered ultramafic profiles in Andowia and Asera which is a part of the North Konawe Regency. The CIA and CIA-K are calculated to determine their correlations to the PGE composition on each horizon. The Pt and Pd measurements were performed using ICP-MS device after preconcentration stage with fire assay technique. The analysis results show that the highest Pt and Pd are available on the horizon just below the topsoil horizon. The highest contents are related to Fe and S composition on each horizon in both study profiles. The $C I A$ and CIA-K indexes are very similar due to the very low potassium oxide content. The weathering index directly proportional to the abundance of $\mathrm{Pt}$ and $\mathrm{Pd}$ on each profile with a very strong correlation. The input inclusion of different places in the Asera's profile is described by the drastic changes of CIA and CIA-K on one horizon. On the other hand, weathering runs normally in Andowia based on a regular increase of CIA and CIA-K from the lowest horizon to the upper one.

Keywords: weathering indexes, platinum-palladium, weathering, ultramafic

\section{PENDAHULUAN}

Platinum Group Elements (PGE) berada dalam Grup VIII, Periode V dan VI logam transisi tabel kimia. Kelompok ini terdiri dari enam unsur logam, yakni: platina $(\mathrm{Pt})$, paladium $(\mathrm{Pd})$, rodium (Rh), iridium (Ir), osmium (Os) dan rutenium $(\mathrm{Ru})$. Bersama emas dan perak, logam PGE merupakan material mahal dengan kelimpahan kecil pada kerak bumi (Ako dkk., 2017). PGE cenderung hadir bersama akibat kemiripan sifat kimia dan fisikanya. Penelitian terhadap kelimpahan PGE banyak dilakukan pada area batuan mafik dan ultramafik (Okrugin, 2011; Liu $d k k .$, 2012; Balaram $d k k .$, 2013; Jackson-Brown $d k k$., 2014; Xing $d k k_{\text {., }}$ 2015; O’Driscoll dan González-Jiménez, 2016; Ako $d k k ., 2017)$. PGE bersifat siderofil karena memiliki afinitas yang tinggi terhadap besi dan bersifat kalkopil karena sering ditemukan bersama dengan tembaga (Liu dkk., 2012; O’Driscoll dan González-Jiménez, 2016). Sulfida diduga sebagai pembawa utama PGE dalam mantel bumi akibat tingkat kelarutannya yang tinggi pada magma jenuh belerang (Okrugin, 2011; Balaram dkk., 2013; O’Driscoll dan González-Jiménez, 2016).

Eksplorasi PGE menjadi sangat menarik akibat faktor geologi, geokimia, biologi, dan proses tektonik yang memengaruhi keterdapatan kelompok unsur ini (Kubrakova dkk., 2017). Studi terkait PGE ini masih sedikit akibat kelimpahan alamiahnya yang kecil dan keterbatasan metode analisis yang akurat (Kubrakova $d k k ., 2017)$. PGE terbagi menjadi Iridium-Platinum Group Elements (IPGE; terdiri dari Ir, Os, dan Ru) yang bersifat sepadan dan Palladium-Platinum Group Elements (PPGE; terdiri dari $\mathrm{Pd}, \mathrm{Pt}$, dan $\mathrm{Rh}$ ) yang cenderung tidak sepadan (Suárez dkk., 2010; Okrugin,
2011; Wang $d k k ., 2011$; Abeng $d k k ., 2012$; Liu $d k k .$, 2012; Balaram dkk., 2013; Xing $d k k .$, 2015; Le Vaillant, Fiorentini dan Barnes, 2016; O’Driscoll dan González-Jiménez, 2016; Ako $d k k ., 2017)$. Oleh sebab itu, IPGE lebih mudah masuk dalam proses kristalisasi mineral selama evolusi magma sedangkan PPGE justru terkonsentrasi tinggi pada magma sisa. IPGE dapat bertahan pada mantel peridotit ketika pelelehan parsial karena bersifat sangat tahan panas. Pada sisi lain, PPGE lebih banyak terdapat pada lelehan sulfida logam yang terpisahkan dari lava induk. Berdasarkan proses pembentukannya mineral pembawa PGE dapat diklasifikasikan menjadi beberapa kelompok mineral, yaitu: (i) berasosiasi dengan logam sulfida, (ii) jenis terbentuk pada tahap awal oksidasi, (iii) oksida PGE, (iv) terikat dengan oksida Fe $( \pm \mathrm{Ni}-\mathrm{Cu})$, dan (vi) ikutan pada hematit-gutit (Suárez $d k k$., 2010). Oleh karena itu, daerah dengan horizon pelapukan $\mathrm{Ni}$ yang tebal sering dijadikan lokasi eksplorasi PGE, seperti: Varshavsky - Urals Selatan (Ankushev $d k k ., 2016)$, dan Aguablanca - Spanyol (Suárez $d k k ., 2010)$.

Pelapukan merupakan fenomena perubahan batuan yang dipengaruhi oleh beragam faktor, seperti: topografi, jenis batuan induk, iklim setempat, dan aktifitas biologi (Calagari, Farahani dan Abedini, 2015). Kondisi tropis dengan temperatur dan curah hujan tinggi secara teoritis akan meningkatkan kecepatan pelapukan batuan. Meski demikian, bila horizon pelapukan sangat tebal, maka proses pelapukan akan jauh melambat akibat pembentukan mineral sekunder yang mengalami pengurangan kation terlarutnya $\left(\mathrm{Ca}^{2+}, \mathrm{Mg}^{2+}, \mathrm{Na}^{+}, \mathrm{K}^{+}\right)$dan bersifat tahan pelapukan (Edwards $d k k$., 2017). Batuan mafik merupakan jenis batuan yang sangat rentan 
terhadap pelapukan sehingga 35\% dari horizon lapuk di wilayah kontinen merupakan hasil dari batuan ini (Edwards dkk., 2017). Terdapat beberapa perhitungan kuantitatif dalam penentuan indeks pelapukan berdasarkan komposisi geokimia, seperti Ruxton Ratio, Weathering Index of Parker, Weathering Potential Index dan Chemical Index of Alteration (ClA). Weathering Potential Index dan Chemical Index of Alteration yang telah diperbarui menjadi Modified Weathering Potential Index dan Chemical Index of Alteration without Potash secara berurutan.

Konawe Utara merupakan kabupaten di wilayah Provinsi Sulawesi Tenggara yang keterdapatan batuan ultramafiknya cukup luas dengan kandungan bahan galian nikel cukup tinggi (Irzon dan Abdullah, 2016). Batuan ultramafik diketahui sebagai batuan yang rentan terhadap pelapukan (Pattnaik dan Equeenuddin, 2016). Keberadaannya dalam lingkungan tropis semakin memudahkan pembentukan horizon laterit nikel di daerah ini. Penelitian terdahulu telah menjabarkan mengenai mobilisasi logam ekonomis ( $\mathrm{Ni}, \mathrm{Fe}$, $\mathrm{Mn}$, dan Co) pada beberapa horizon laterit nikel di wilayah Sulawesi Tenggara tersebut (Chaerul dkk., 2015; Irzon, 2017). Peta pengembangan kawasan andalan pertambangan nikel di Kabupaten Konawe Utara ditunjukkan pada Gambar 1.

Studi mengenai keterdapatan PGE pada horizon laterit nikel di Konawe Utara pada dasarnya belum pernah dilakukan. Penelitian ini bertujuan menjabarkan kandungan dua jenis PPGE yakni platina dan paladium pada dua profil laterit nikel di Konawe Utara. Profil yang dipelajari adalah yang tersingkap di Andowia dan Asera. Indeks pelapukan berdasarkan komposisi kimia dikalkulasi untuk mengetahui korelasinya dengan keadaan megaskopis di lapangan maupun dengan komposisi PGE pada masing-masing horizon. Studi ini bermanfaat untuk memfokuskan eksplorasi PGE pada horizon tertentu dalam profil hasil pelapukan batuan ultramafik.

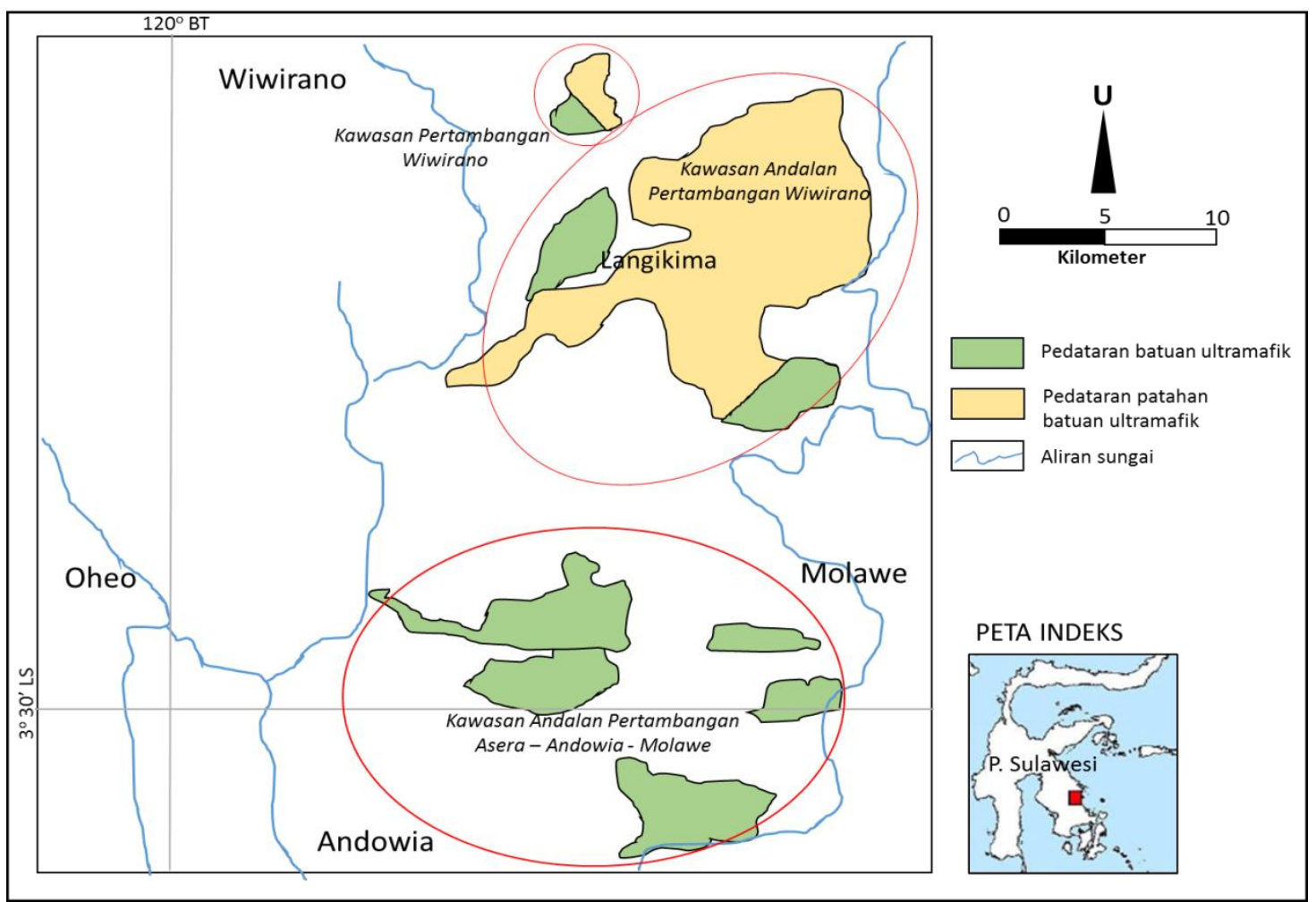

Sumber: Nursahan, Isnaniawardhani dan Sulaksana (2013)

Gambar 1. Peta pengembangan kawasan andalan pertambangan nikel di Kabupaten Konawe Utara. 


\section{Geologi Regional}

Konawe Utara merupakan bagian dari Peta Geologi Lembar Lasusua - Kendari (Rusmana $d k$., 1993). Formasi Tolaka dan Formasi Meluhu merupakan dua unit batuan tertua yang terdapat di sini. Kedua satuan batuan terdiri dari batuan metasedimen berumur Trias dan berada di Selatan Kabupaten Konawe Utara. Kompleks Ultramafik dengan kisaran peridotit, harsburgit, dunit, gabro, dan serpentinit berada di utara kabupaten ini. Formasi Pandua tersedimentasi pada waktu Miosen Akhir - Pliosen Awal dan tersusun oleh konglomerat, batu pasir dan lempung. Batuan termuda di lembar peta ini ialah Aluvium (berumur Kuarter) yang terdiri dari endapan sungai, rawa dan pantai. Penelitian terdahulu telah membagi Kompleks Ultramafik ini berdasarkan interpretasi petrologi dan komposisi geokimianya (Irzon dan Abdullah, 2016).

Kedua profil nikel laterit yang dipelajari berada di Kabupaten Konawe Utara dan berlokasi tidak jauh dari jalan raya sehingga mudah untuk dicapai. Batuan induk tidak tersingkap pada kedua profil untuk dapat mempelajari proses mobilisasi PGE secara lebih komprehensif. Namun demikian, berdasarkan peta geologi dan kenampakan horizon pelapukan secara megaskopis, kedua profil ini merupakan hasil pelapukan batuan ultramafik. Kedua lokasi profil pengamatan berikut keadaan geologi lokal wilayah Konawe Utara dapat dilihat pada Gambar 2.

\section{METODE}

Penelitian dimulai dengan pengambilan percontoh pada dua lokasi di Konawe Utara. Palu geologi, kompas, lup, dan meter ukur diperlukan untuk mendeskripsikan setiap horizon penelitian dan memisahkan percontoh yang akan diteliti. Setelah sampai di laboratorium, percontoh terpilih dipreparasi, kemudian dianalisis menggunakan inductively coupled plasma - mass spectrometry (ICP-MS).

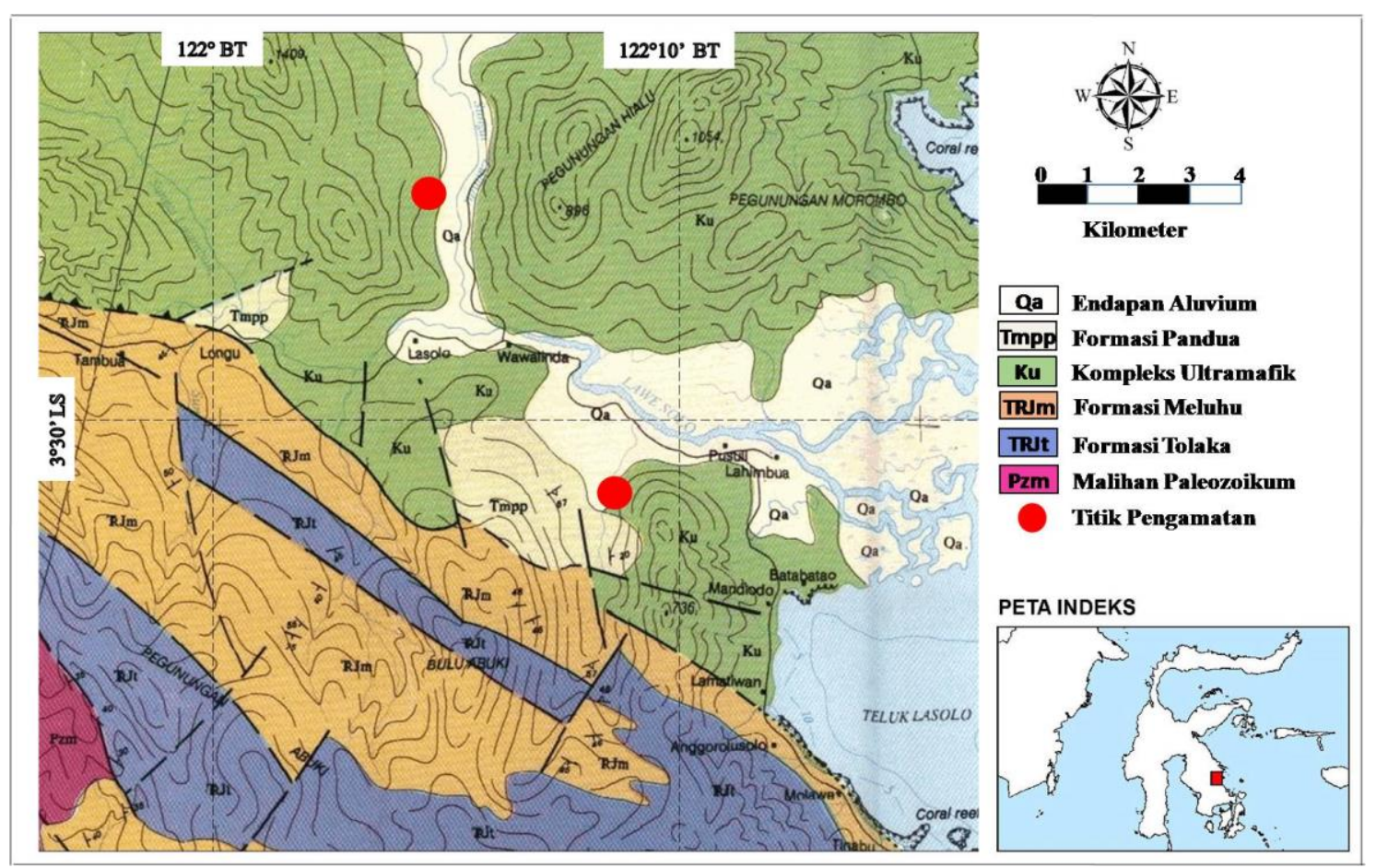

Sumber: Rusmana dkk. (1993)

Gambar 2. Geologi lokal Kabupaten Konawe Utara berikut lokasi profil penelitian di Andowia dan di Asera 


\section{Megaskopis Dua Profil Penelitian}

Profil pertama berada di sekitar Andowia berupa hasil pelapukan batuan ultramafik dengan ketebalan total mencapai $3 \mathrm{~m}$ (KUR 57). Pada profil ini dapat diamati empat horizon yang berbeda. Pertama, horizon saprolit dengan tipikal batuan yang sudah lapuk namun masih cukup keras dengan ketebalan $1 \mathrm{~m}$ tersingkap paling bawah. Pada horizon kedua dapat diamati saprolit yang relatif lebih lapuk (KUR 57 C) daripada KUR $57 \mathrm{D}$ memiliki ketebalan 0,5 $\mathrm{m}$ dan berbatasan dengan horizon ketiga (laterit). Laterit pada profil di Andowia (KUR 57 B) memiliki ketebalan $0,5 \mathrm{~m}$ dengan warna gelap yang diduga akibat pelapukan besi. Mineral lempungan juga dapat dijumpai pada horizon KUR 57 B ini. Top soil secara megaskopis masih berwarna merah gelap meski tanpa mineral lempungan dan masih dijumpai akar-akar tanaman. Tebal horizon paling atas ini sekitar satu meter (KUR 57-A). Studi sebelumnya telah menjabarkan perbandingan komposisi logam-logam berat, kecuali PGE, pada empat horizon pada profil di Andowia (Irzon, 2017).
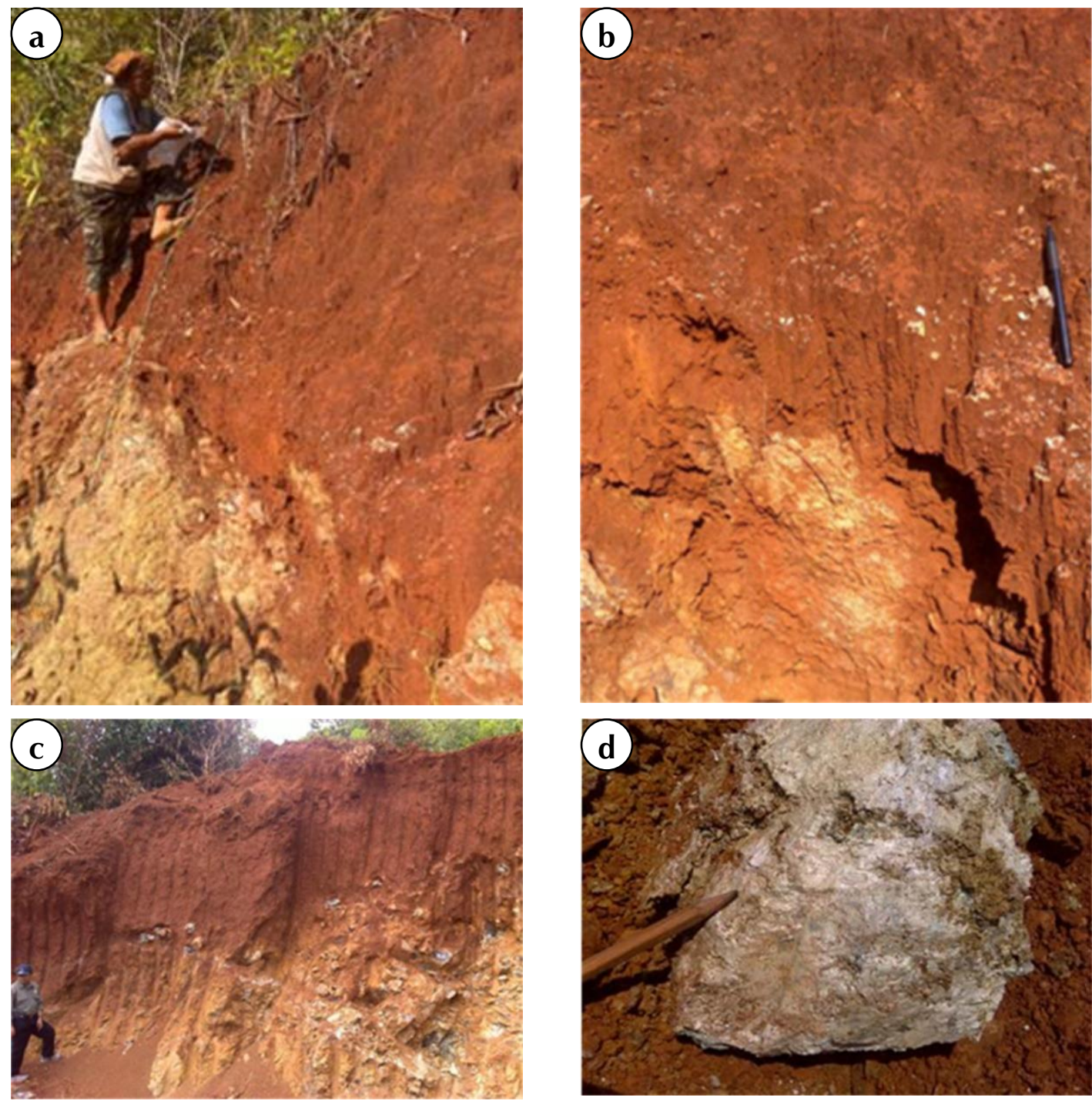

Sumber: Irzon (2017)

Gambar 3. Kenampakan megaskopis profil penelitian: a) Profil di Andowia; b) Batas horizon saprolit dan laterit di Andowia; c) Profil pelapukan di Asera yang dapat dibagi menjadi tujuh horizon; dan d) Saprolit berwarna terang dari horizon UMK 53-7 di Asera 
Profil berikutnya berada di wilayah Asera (UMK 53) dengan ketebalan total 3,1 m. Meski pada dasarnya profil ini terdiri dari tiga bagian, yaitu: saprolit, laterit/limonit, maupun tanah penutup, profil ini dapat dibedakan lebih jauh menjadi tujuh horizon. Saprolit dengan warna terang (UMK 53-7) dan ketebalan $60 \mathrm{~cm}$ berada paling bawah sebagai lapisan yang paling sedikit mengalami pelapukan bila dibandingkan dengan yang lain. Saprolit berwarna kekuningan (UMK 53-6) menindih di atas saprolit berwarna terang memiliki ketebalan setengah meter. Meskipun telah berwarna kemerahan, lapisan di atas UMK 536 masih digolongkan sebagai saprolit karena masih terdapat sisa batuan induk. Horizon yang berbatasan dengan laterit ini (UMK 53-5) memiliki ketebalan $30 \mathrm{~cm}$. Laterit terbagi dalam dua horizon dengan kenampakan warna yang berbeda dari bawah ke atas, yakni: berwarna kemerahan (UMK 53-4) dan merah kehitaman (UMK 53-3) dengan tebal lapisan masing-masing $40 \mathrm{~cm}$. Berbeda dengan profil di Andowia, profil di Asera ini bukan dihasilkan oleh pelapukan secara keseluruhan karena didapati fragmen batuan pada lapisan koluvium (UMK 53-2) sebagai lepasan dari tempat lain (tebal horizon $\approx 60 \mathrm{~cm}$ ). Akar-akar tanaman masih dapat diamati pada lapisan teratas sebagai horizon tanah penutup yang berwarna merah gelap dengan ketebalan 30 cm (UMK 53-1). Keadaan lapangan profil lapukan batuan ultramafik yang dipelajari dapat dilihat pada Gambar 3. Ringkasan kedua profil dapat diamati pada Gambar 4.

\section{Pengukuran Kadar Pt dan Pd}

Platina dan paladium pada seluruh percontoh telah diukur di Laboratorium Geologi - Pusat Survei Geologi. Seperti telah dipaparkan sebelumnya, PGE terdapat di alam dalam kelimpahan yang kecil sehingga dibutuhkan metode dengan ketelitian pengukuran yang tinggi. Oleh karena itu, perangkat utama yang digunakan adalah ICP-MS sebagai perangkat yang robust dan sensitif sehingga mampu mendeteksi kadar unsur dan/atau isotop hingga part per billion (ppb) (Liu dkk., 2012; Xing $d k k .$, 2015; Ako dkk., 2017; Irzon, 2017; Gilmartin dan Gingrich, 2018). Selain itu, seluruh percontoh telah melalui proses prakonsentrasi dengan skema uji kadar logam agar jumlah PGE pada percontoh dapat lebih mudah dibaca oleh spektrometer massa dalam ICP-MS. Skema uji kadar logam yang telah dijabarkan pada penelitian sebelumnya juga diterapkan pada studi mengenai pelapukan batuan ultramafik (Irzon dan Kurnia, 2013, 2014). Proses preparasi percontoh konsentrat hasil uji kadar logam hingga analisis dengan ICP-MS mengikuti alur kerja studi sebelumnya (Irzon, 2017). Berdasarkan lima tingkat larutan standar kalibrasi yang digunakan maka limit deteksi Pd dan Pt pada studi ini adalah 2 dan 1 ppb secara berurutan.
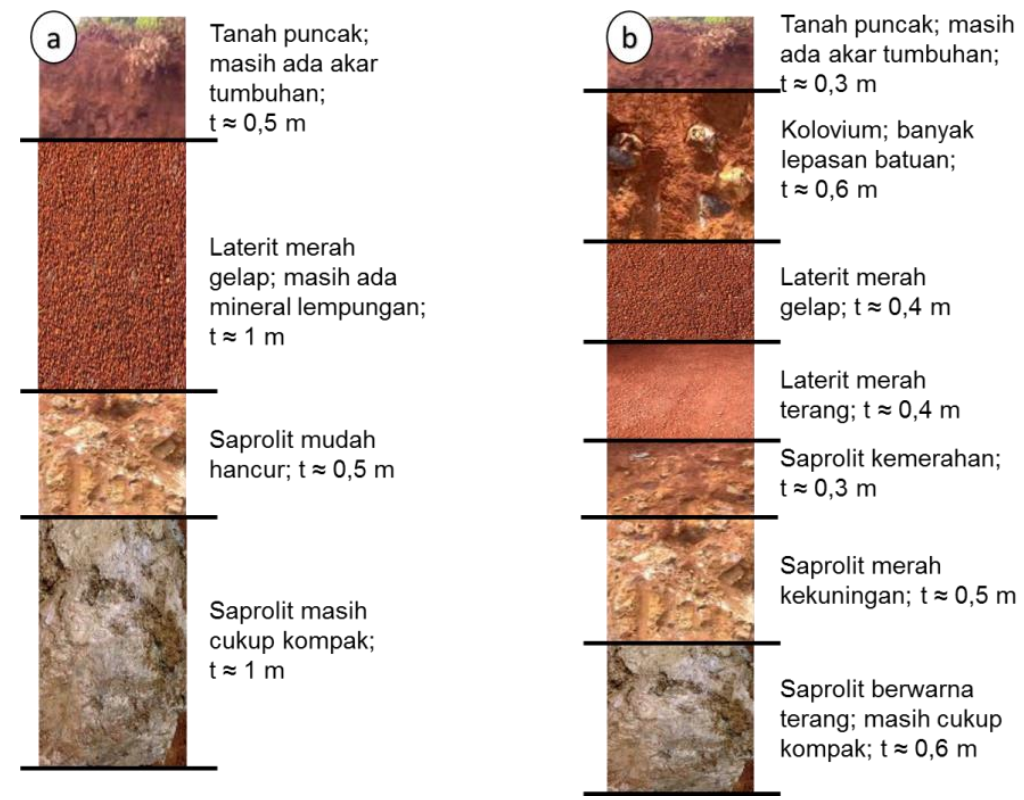

Gambar 4. Deskripsi setiap horizon pada dua profil penelitian: a) Andowia dan b) Asera 


\section{HASIL DAN PEMBAHASAN}

\section{Hasil Analisis}

Mobilisasi oksida utama, beberapa unsur jejak, dan unsur tanah jarang pada profil di Andowia telah dibahas pada studi sebelumnya (Irzon, 2017). Namun demikian kedua penelitian tersebut belum membahas mengenai kelimpahan PGE maupun indeks pelapukan berbasis geokimia pada kedua profil. Dikenal sebagai logam bernilai ekonomis tinggi, kandungan PGM secara alami memang sangat rendah yang biasanya pada level ppb. Secara rata-rata, paladium pada percontoh lebih tinggi dibandingkan dengan kelimpahannya pada mantel, meski Pt terdeteksi lebih rendah. Kadar Pd pada profil di Andowia memilki rentang yang lebih lebar dari pada Asera, yaitu: 4 hingga 8 ppb (rataan 5,75 ppb) dan 4 hingga 7 ppb (rataan 5,57 ppb) secara berurutan. Sebaliknya, profil di Asera terdeteksi dengan rentang Pt yang lebih luas $(3-6 \mathrm{ppb}$, rerata $4,14 \mathrm{ppb}$ ) dari pada Andowia (2 - $4 \mathrm{ppb}$, rerata 2,75 ppb).

Dua jenis indeks pelapukan berbasis geokimia diterapkan pada penelitian ini, yaitu chemical index of alteration (ClA) dan chemical index of alteration without potash (CIA-K). $\mathrm{CIA}$ dihitung dengan persamaan berturut-turut (1) dan (2) berikut:

$$
\frac{\mathrm{Al}_{2} \mathrm{O}_{3}}{\mathrm{Al}_{2} \mathrm{O}_{3}+\mathrm{CaO}+\mathrm{Na}_{2} \mathrm{O}+\mathrm{K}_{2} \mathrm{O}} \times 100
$$

$\frac{\mathrm{Al}_{2} \mathrm{O}_{3}}{\mathrm{Al}_{2} \mathrm{O}_{3}+\mathrm{CaO}+\mathrm{Na}_{2} \mathrm{O}} \times 100$

CIA-K adalah hasil penyempurnaan CIA dengan tidak memasukkan kadar oksida kalium dalam perhitungannya. Perbedaan cukup signifikan terindikasi pada indeks pelapukan berbasis kandungan geokimia. Rentang $\mathrm{ClA}$ dan $\mathrm{ClA}-\mathrm{K}$ yang sempit ditunjukkan oleh profil di Andowia, yakni masing-masing berkisar antara 68,1 - 95,6 dan 68,2 - 95,8. Pada sisi lain, indeks pelapukan yang lebih lebar ditunjukkan oleh profil di Asera dengan CIA pada 47,24 hingga 92,63 dan CIA-K pada 47,46 hingga 92,84. Hasil pengukuran kelimpahan $\mathrm{Pt}$ dan $\mathrm{Pd}$ berikut indeks pelapukan pada percontoh dalam studi ini terlampir dalam Tabel 1. Hasil kalkulasi perhitungan $\mathrm{CIA}$ dan $\mathrm{CIA}-\mathrm{K}$ berdasarkan persamaan (1) dan (2) sangat mirip akibat sangat rendahnya kadar $\mathrm{K}_{2} \mathrm{O}$ pada setiap percontoh sebagai hasil pelapukan batuan ultramafik.

\section{Perubahan Kadar Pt dan Pd}

Platina berkadar paling rendah ditunjukkan oleh dua horizon saprolit di Andowia (KUR 57 C dan KUR 57 D) sebesar 2 ppb. Kelimpahan platina jauh meningkat menjadi 4 ppb pada horizon laterit berwarna merah gelap (KUR 57 B). Meski jumlah platina sedikit turun menjadi 3 ppb pada horizon tanah, jumlah ini meningkat $75 \%$ bila dibandingkan dengan kadar dalam horizon saprolit. Kecenderungan mobilisasi paladium relatif serupa dengan platina pada profil ini. Paladium pada laterit naik drastis hingga mencapai dua kali lipat pada horizon laterit (8 ppb) relatif terhadap horizon saprolit bagian bawah maupun horizon saprolit bagian atas (4 ppb) (Gambar 5a).

Walaupun saprolit dapat dibedakan menjadi tiga horizon (UMK 53-5, UMK 53-6, dan UMK 53-7) berbeda pada profil di Asera, kandungan Pt dan Pd tidak berubah dan merupakan yang paling rendah, yakni 3 dan 4 ppb secara berurutan. Jumlah $\mathrm{Pd}$ meninggi pada horizon laterit bawah (UMK 53-4) dan makin naik menuju horizon laterit atas (UMK 53-3) menjadi masing-masing 6 dan 7 ppb. Tidak terdapat perubahan kadar paladium pada lapisan koluvium (UMK 53-2) dan tanah penutup (UMK 53-1) secara komparatif terhadap horizon laterit bagian atas. Sedikit perbedaan dapat diperhatikan pada pola mobilisasi platina. Komposisi platina tampak stabil pada tiga lapisan saprolit (3 ppb) dan terus meningkat pada tiga lapisan ke atas berikutnya, yaitu: 4, 5, dan 6 ppb dalam lapisan laterit bawah, laterit atas, dan koluvium secara berurutan. Kandungan logam mulia dengan nomor atom 78 ini sedikit menurun menjadi 5 ppb pada lapisan tanah (Gambar 5b). Lepasan batuan dari tempat lain menjadi faktor pembeda pada profil di Andowia terhadap profil dari Asera sehingga lapisan tanah penutup di tempat yang terakhir memiliki jumlah Pd dan Pt yang sama dengan lapisan laterit teratas. Berdasarkan pola mobilisasi kedua profil yang diteliti dapat disimpulkan bahwa secara normal $\mathrm{Pd}$ dan $\mathrm{Pt}$ tertinggi terdapat pada horizon yang tepat berada di bawah horizon tanah penutup. 
Tabel 1. Komposisi Pt dan Pd pada seluruh percontoh dan hasil perhitungan indeks pelapukan berbasis geokimia

\begin{tabular}{lcccc}
\hline & \multicolumn{2}{c}{ Konsentrasi PGE $(\mathbf{p p b})$} & \multicolumn{2}{c}{ Indeks Pelapukan } \\
\cline { 2 - 5 } & Pt & Pd & CIA & CIA-K \\
\hline Profil di Andowia & & & & \\
KUR 57 A & 3 & 7 & 95.6 & 95.8 \\
KUR 57 B & 4 & 8 & 95.1 & 95.3 \\
KUR 57 C & 2 & 4 & 68.99 & 69 \\
KUR 57 D & 2 & 4 & 68.1 & 68.2 \\
\hline Profil di Asera & & & & \\
UMK 53-1 & 5 & 7 & 92.63 & 92.84 \\
UMK 53-2 & 6 & 7 & 47.97 & 48.01 \\
UMK 53-3 & 5 & 7 & 88.59 & 88.69 \\
UMK 53-4 & 4 & 6 & 87.23 & 87.28 \\
UMK 53-5 & 3 & 4 & 51.64 & 51.71 \\
UMK 53-6 & 3 & 4 & 49.74 & 49.81 \\
UMK 53-7 & 3 & 4 & 47.24 & 47.46 \\
\hline
\end{tabular}
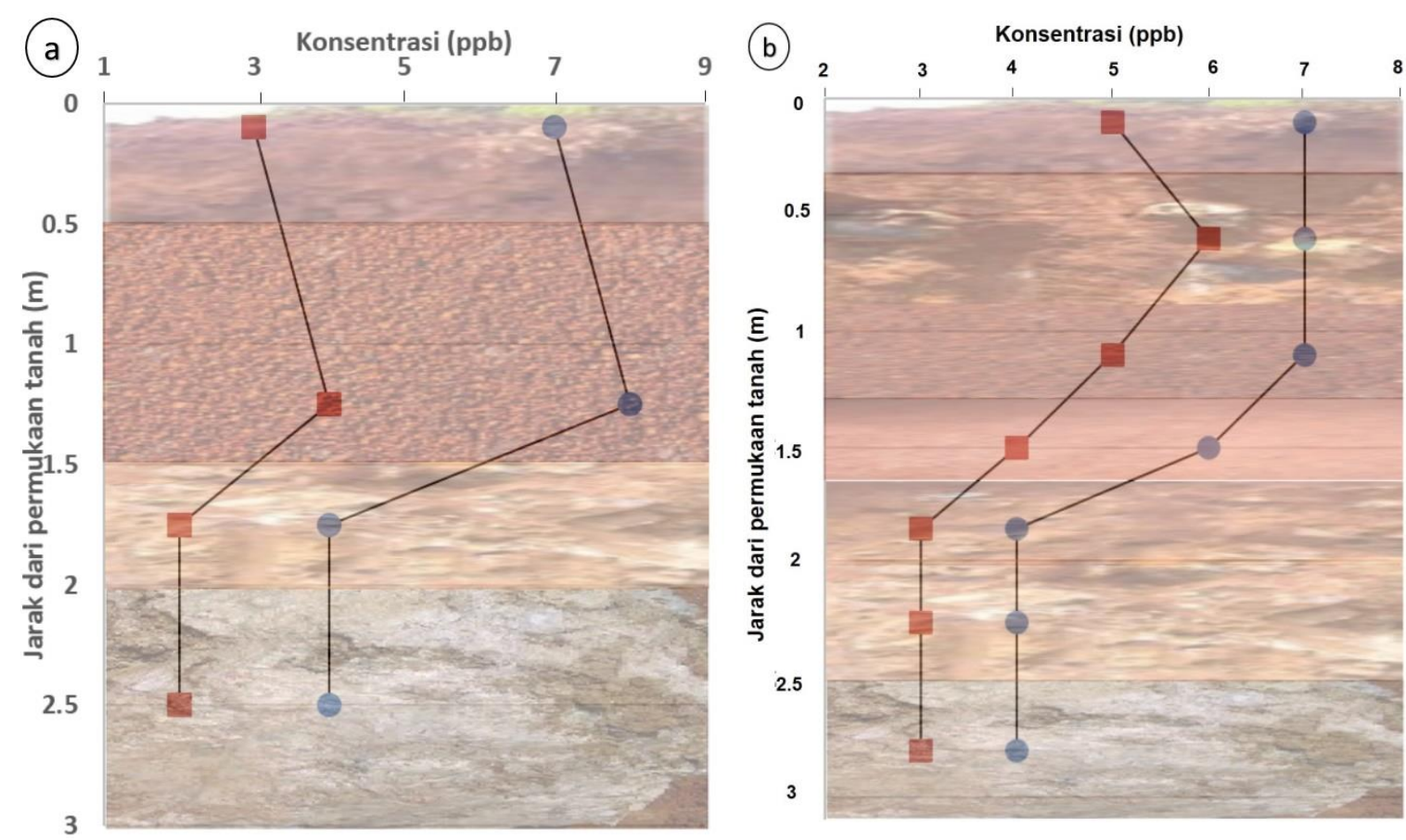

Gambar 5. Perubahan kadar PGE

$=$ Pt dan $\bigcirc=$ Pd) pada setiap horizon di kedua profil penelitian: a) di Andowia; dan b) di Asera

Kadar oksida besi berkorelasi sangat kuat terhadap Pd di Andowia dan Pt maupun Pd di Asera yang sesuai dengan kesimpulan sebelumnya bahwa Platinum Group Element bersifat siderofil (Liu dkk., 2012; O'Driscoll dan González-Jiménez, 2016). Meski tidak sekuat korelasi sebelumnya Pt terhadap $\mathrm{Fe}_{2} \mathrm{O}_{3} \mathrm{~T}$ masih berkorelasi kuat pada profil di Andowia dengan koefisien korelasi 0,79 (Tabel 2). Kecenderungan yang sama dapat diamati pada korelasi kedua logam PGE di dua profil yang dipelajari, yakni: korelasi sangat kuat $\mathrm{Pt}_{-} \mathrm{SO}_{3} \mathrm{di}$ Andowia dan $\mathrm{Pt}_{-} \mathrm{SO}_{3}$ dan $\mathrm{Pd}-\mathrm{SO}_{3}$ di Asera sebagai penegas bahwa PPGE terkonsentrasi pada material sulfida (Le Vaillant, Fiorentini dan Barnes, 2016). Namun demikian, kenaikan komposisi nikel berbanding terbalik dengan kelimpahan Pd dan Pt di kedua titik penelitian. $\mathrm{Ni}$ lebih terkonsentrasi pada batas antara horizon saprolit dan laterit (Irzon, 2017) sedangkan kadar PGE tertinggi justru berada pada horizon sebelum tanah. Partikel logam 
ukuran nanometer dapat terbentuk selama proses pelapukan. Penelitian sebelumnya menyebutkan bahwa selain Fe oksihidroksi, bahan organik disimpulkan dapat membantu migrasi PGE (Kubrakova dkk., 2017). Pt dan Pd pada lokasi studi sangat mungkin telah termobilisasi menuju horizon paling atas dengan bantuan penyerapan tumbuhan yang terdapat pada horizon ini sehingga dapat menjelaskan kandungannya yang lebih tinggi daripada horizon saprolit.

\section{Indeks Pelapukan Berbasis Geokimia}

Penelitian sebelumnya telah menyimpulkan bahwa tingkat pelapukan di Andowia meningkat dari horizon paling bawah menuju ke atas (Irzon, 2017). Sedikit perbedaan pada profil di Asera adalah keterdapatan horizon koluvium. Indeks pelapukan $\mathrm{CIA}$ dan $\mathrm{CIA}-\mathrm{K}$ dimanfaatkan untuk menganalisis tingkat pelapukan secara berbasis komposisi geokimia pada dua profil yang dipelajari. Perbedaan horizon saprolit dan laterit tampak jelas pada indeks pelapukan di Andowia (Gambar 6a). $\mathrm{CIA}$ maupun $\mathrm{CIA}-\mathrm{K}$ pada dua horizon saprolit tidak jauh berbeda, yaitu 68,1 dan 68,2 pada KUR 57 D; dan 68,99 dan 69 pada KUR 57 C. Indeks ini menaik pada horizon laterit $(\mathrm{CIA}=$ 95,1 dan CIA-K = 95,3) yang bermakna bahwa pelapukan kuat telah terjadi. Meski sedikit menaik, dua jenis indeks pelapukan tidak jauh berbeda antara lapisan laterit dan tanah penutup.

Batas antara horizon saprolit maupun laterit pada profil di Asera dipertegas oleh indeks CIA dan CIA-K. Dua indeks tersebut perlahan meningkat dari horizon saprolit paling bawah (UMK 53-7) hingga saprolit paling atas (UMK 53-5) (Gambar 6b). Sedikit kenaikan CIA dan CIA-K dapat diperhatikan pada horizon laterit UMK 53-4 menuju UMK 53-3. Perlu ditekankan bahwa kedua indeks pelapukan ini jauh meningkat dari horizon saprolit yang berkisar antara 47 hingga 52 menuju laterit dengan indeks 87-89. Profil pelapukan semakin jelas telah terganggu oleh input dari luar dengan penurunan signifikan $\mathrm{CIA}$ dan $\mathrm{CIA}-\mathrm{K}$ pada UMK 53-3 terhadap UMK 53-2. Input dari lokasi lain dapat dikategorikan sebagai batuan yang relatif dengan tingkat pelapukan setara dengan saprolit pada profil ini dengan mengacu pada dua jenis indeks pelapukan. $\mathrm{CIA}$ dan CIA-K kembali meningkat hingga mencapai nilai paling tinggi pada horizon teratas dari profil di Asera.

Tingkat pelapukan menaik berbanding lurus dengan peningkatan nilai ClA. Batuan dianggap masih cukup segar dengan $\mathrm{ClA} \leq 50$, sedangkan batas optimum batuan yang telah lapuk adalah $\mathrm{CIA}=100$ (Taboada dkk., 2016; Singh dan Khan, 2017). Lebih lanjut, sistematika proses pelapukan dikatakan berada pada tingkat sedang dengan CIA 60-80, sedangkan $\mathrm{ClA}>80$ adalah indikasi tingkat pelapukan berat (Engon $d k k$., 2017). Berdasarkan pada klasifikasi tersebut dua horizon laterit di Andowia dikategorikan lapuk sedang, sedangkan horizon laterit dan top soil telah lapuk berat. Kecenderungan yang serupa juga ditunjukkan pada profil di Asera. Tiga horizon saprolit (UMK 53-7 hingga UMK 53-5) di Asera terbukti baru saja mulai lapuk. UMK 53-4 dan UMK 53-3 terbukti telah pengalami pelapukan tingkat tinggi. Penurunan drastis CIA pada UMK 53-2 dipengaruhi oleh koluvium pada horizon ini.

\section{Korelasi Kadar PGM terhadap Indeks Pelapukan}

Perubahan komposisi PGM terhadap indeks pelapukan perlu dikaji untuk mengetahui kecenderungannya. Hubungan kedua variabel tersebut dipelajari dengan perhitungan koefisien korelasi (r). Semakin kuat korelasi antara dua variabel maka koefisien korelasinya akan semakin mendekati 1 atau -1. Paladium tampak berkorelasi lebih kuat terhadap indeks pelapukan pada dua profil pelapukan batuan ultramafik yang diteliti. Variabel kelimpahan paladium dan platina berkorelasi positif sangat kuat terhadap kedua indeks pelapukan berbasis geokimia di Andowia, yaitu 0,98 dan 0,90 secara berurutan (Tabel 2). Kecenderungan serupa juga dapat diamati pada profil di Asera bila kedua variabel yang dikorelasikan adalah data pada horizon UMK 53-3 ke bawah hingga UMK 53-7. Pada sisi lain, tidak ada korelasi yang berderajat cukup kuat jika seluruh data pada profil di Asera digunakan dalam perhitungan, yaitu koefisien korelasi 0,39 (Pt) dan 0,67 (Pd). Hal ini semakin mempertegas hasil penelitian sebelumnya (Irzon, 2017) bahwa horizon UMK 53-2 (collovium) bukanlah hasil pelapukan menerus dari batuan induk yang sama dengan horizon-horizon di bawahnya. 

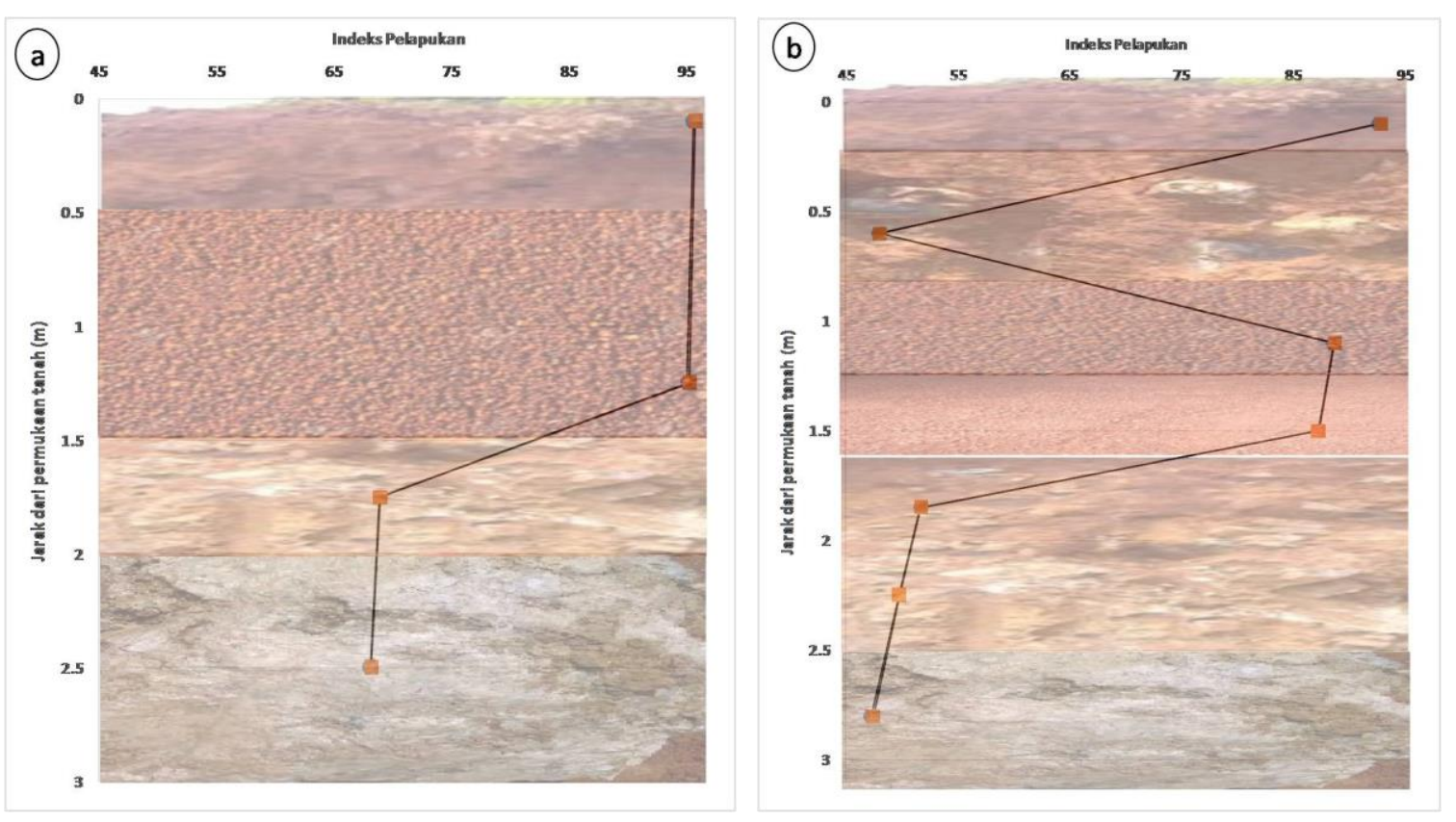

Gambar 6. Indeks pelapukan pada dua profil yang diteliti: a) di Andowia; dan b) di Asera.

Keterangan: $\square=\mathrm{CIA}-\mathrm{K}$ dan $\bigcirc=\mathrm{ClA}$. Perbedaan kedua indeks pelapukan ini tidak tampak jelas pada profil di Asera akibat nilai yang sangat mirip.

Tabel 2. Koefisien korelasi ( $r$ ) antara komposisi Pt dan Pd pada profil penelitian terhadap kadar oksida besi, oksida sulfur, dan dua jenis indeks pelapukan.

\begin{tabular}{lccccc}
\hline \multicolumn{1}{c}{ Profil } & & $\mathrm{Fe}_{2} \mathrm{O}_{3 \mathrm{~T}}$ & $\mathrm{SO}_{3}$ & $\mathrm{ClA}$ & $\mathrm{ClA}-\mathrm{K}$ \\
\hline \multirow{2}{*}{ Andowia } & $\mathrm{Pt}$ & 0,79 & 0,77 & 0,90 & 0,90 \\
& $\mathrm{Pd}$ & 0,91 & 0,89 & 0,98 & 0,98 \\
\hline \multirow{2}{*}{ Asera tanpa dua horizon teratas } & $\mathrm{Pt}$ & 0,96 & 0,90 & 0,92 & 0,93 \\
& $\mathrm{Pd}$ & 0,99 & 0,95 & 0,97 & 0,97 \\
\hline \multirow{2}{*}{ Asera keseluruhan } & $\mathrm{Pt}$ & 0,55 & 0,63 & 0,39 & 0,39 \\
& $\mathrm{Pd}$ & 0,77 & 0,81 & 0,67 & 0,67 \\
\hline
\end{tabular}

\section{KESIMPULAN DAN SARAN}

Komposisi platina pada profil di Andowia berada dalam rentang yang sedikit lebih rendah daripada di Asera. Sebaliknya, kadar paladium pada tujuh horizon laterit nikel di Asera relatif sedikit lebih rendah dibanding di Andowia. Berdasarkan data pada kedua lokasi studi Pt dan Pd tertinggi berada pada horizon yang berada tepat di bawah horizon top soil yang diduga terkait komposisi Fe dan S pada setiap horizon. Indeks $\mathrm{CIA}$ dan $\mathrm{CIA}-\mathrm{K}$ telah dihitung dan disimpulkan bahwa kedua variabel tersebut sangat mirip akibat kandungan oksida potasium yang sangat rendah pada setiap percontoh. Indeks pelapukan berbanding lurus dengan kelimpahan $\mathrm{Pt}$ dan $\mathrm{Pd}$ pada setiap profil dengan korelasi sangat kuat. Keterdapatan input dari tempat berbeda pada profil di Asera juga dipertegas dengan perubahan nilai indeks pelapukan berbasis geokimia.

Hasil yang diperoleh pada studi ini dapat mempermudah eksplorasi PGE pada berbagai lokasi lain. Pengaruh tetumbuhan pada penyerapan nanopartikel PGE yang kemudian memengaruhi migrasi logam ini perlu dipertegas melalui studi-studi lainnya.

\section{UCAPAN TERIMA KASIH}

Penulis mengucapkan terimakasih sebesarbesarnya kepada Kepala Pusat Survei Geologi atas izin penggunaan data dalam tulisan ini. 
Tulisan ini merupakan bagian dari proyek penelitian batuan ultramafik di Konawe Utara yang telah dimulai sejak 2014. Terimakasih kami ucapkan kepada Prof. Ildrem Syafri dan Bapak Johannes Hutabarat yang telah memberi pengarahan mengenai penggunaan data geokimia. Kami ucapkan banyak terimakasih juga kepada Ibu Erna, Ibu Indah, dan Ibu Citra atas pendampingannya dalam rangkaian uji laboratorium.

\section{DAFTAR PUSTAKA}

Abeng, S. A., Ndjigui, P.-D., Beyanu, A. A., Teutsong, T. dan Bilong, P. (2012) "Geochemistry of pyroxenites, amphibolites and their weathered products in the Nyong unit, SW Cameroon (NW border of Congo craton): Implications for Au-PGE exploration," Journal of Geochemical Exploration, 114, hal. 1-19. doi: 10.1016/j.gexplo.2011.11.003.

Ako, T. A., Vishiti, A., Suh, C. E., Kedia, A. C. dan Omang, B. O. (2017) "Geological models of platinum group elements (PGE) depletion in metamorphosed ultramafic rocks of the Nyong series, Southeast Cameroon," International Journal of Mining Science, 3(4), hal. 52-63. doi: 10.20431/2454-9460.0304005.

Ankushev, M. N., Zaykov, V. V., Kotlyarov, V. A. dan Romanenko, M. E. (2016) "Chrome spinels and accessory mineralization in the weathering crust of the Vladimir deposit, Varshavsky ultramafic massif, southern Urals," Ceology of Ore Deposits, 58(8), hal. 697-710. doi: 10.1134/S1075701516080031.

Balaram, V., Singh, S. P., Satyanarayanan, M. dan Anjaiah, K. V (2013) "Platinum group elements geochemistry of ultramafic and associated rocks from Pindar in Madawara Igneous Complex, Bundelkhand massif, central India," Journal of Earth System Science, 122(1), hal. 79-91. doi: 10.1007/s12040-012-0260-0.

Calagari, A. A., Farahani, F. K. dan Abedini, A. (2015) "Geochemical characteristics of laterite: the Jurassic Zan deposit, Iran," Acta Geodynamica et Geomaterialia, 12(1), hal. 67-77. doi: 10.13168/AGG.2015.0001.

Chaerul, M., Pallu, M. S., Selintung, M. dan Patanduk, J. (2015) "Distribution and mobility of heavy metal materials in settling ponds post laterite nickel mining (A case study: North Motui Konawe, Southeast Sulawesi)," International Journal of Engineering Research and Applications, 5(6), hal. 72-75. Tersedia pada:

https://www.ijera.com/papers/Vol5 issue6/Par t - 2/M56027275.pdf.

Edwards, D. P., Lim, F., James, R. H., Pearce, C. R., Scholes, J., Freckleton, R. P. dan Beerling, D. J. (2017) "Climate change mitigation: potential benefits and pitfalls of enhanced rock weathering in tropical agriculture," Biology Letters, 13(4), hal. 20160715. doi: 10.1098/rsbl.2016.0715.

Engon, T. C., Abane, M. A.-A., Zo'o Zame, P., Ekomane, E., Bekoa, E., Mvogo, K. dan Bitom, D. (2017) "Morphological, physicochemical and geochemical characterization of two weathering profiles developed on limestone from the Mintom Formation in the tropical humid zone of Cameroon," Journal of African Earth Sciences, 131, hal. 198-212. doi: 10.1016/j.jafrearsci.2017.03.026.

Gilmartin, G. dan Gingrich, D. (2018) "A comparison of the determination and speciation of inorganic arsenic using general HPLC methodology with UV, MS and MS/MS detection," Journal of Chromatography B, 1083, hal. 20-27.

doi: 10.1016/j.jchromb.2018.02.034.

Irzon, R. (2017) "Pengayaan logam berat Mn, Co, dan $\mathrm{Cr}$ pada laterit nikel di Kabupaten Konawe Utara, Provinsi Sulawesi Tenggara," Buletin Sumber Daya Geolog, 12(2), hal. 7186. Tersedia pada:

http://buletinsdg.geologi.esdm.go.id/index.ph p/bsdg/article/view/BSDG_VOL_12_NO_2_2 0171.

Irzon, R. dan Abdullah, B. (2016) "Geochemistry of Ophiolite Complex in North Konawe, Southeast Sulawesi," EKSPLORIUM, 37(2), hal. 101-114. doi: 10.17146/eksplorium.2016.37.2.2868.

Irzon, R. dan Kurnia (2013) "Kondisi temperatur, waktu, dan $\mathrm{pH}$ reaksi untuk mengoptimasi prosedur standar analisa platinum dengan ekstraksi atomic absorption spectrometry," Jurnal Geologi dan Sumberdaya Mineral, 14(4), hal. 51-58. Tersedia pada: http://jgsm.geologi.esdm.go.id/index.php/JGS M/article/view/78

Irzon, R. dan Kurnia (2014) "Optimasi teknik fire assay dan kondisi kupelasi untuk memperoleh komposisi fluks terbaik pada analisis kadar emas," Jurnal Geologi dan Sumberdaya Mineral, 15(1), hal. 55-62. Tersedia pada: http://jgsm.geologi.esdm.go.id/index.php/JGS M/article/view/70 
Jackson-Brown, S., Scoates, J. S., Nixon, G. T. dan Ames, and D. E. (2014) "Mineralogy of sulphide, arsenide, and platinum group minerals from the DJ/DB Zone of the Turnagain Alaskan-type ultramafic intrusion, north-central British Columbia.," in Geological Fieldwork 2013: A Summary of Field Activities and Current Research. Vancouver: British Columbia Geological Survey, hal. 157-168. Tersedia pada:

http://www.empr.gov.bc.ca/Mining/Geoscienc e/PublicationsCatalogue/Fieldwork/Documents /2013/09_Jackson-Brown_etal.pdf.

Kubrakova, I. V., Tyutyunnik, O. A., Koshcheeva, I. Y., Sadagov, A. Y. dan Nabiullina, S. N. (2017) "Migration behavior of platinum group elements in natural and technogeneous systems," Geochemistry International, 55(1), hal. 108-124.

doi: 10.1134/S0016702916120053.

Liu, Q., Hou, Q., Xie, L., Li, H., Ni, S. dan Wu, Y. (2012) "Different origins of the fractionation of patinum-group elements in raobazhai and bixiling mafic-Ultramafic rocks from the dabie orogen, Central China," Journal of Ceological Research, 2012, hal. 1-11.

doi: 10.1155/2012/631426.

Nursahan, I., Isnaniawardhani, V. dan Sulaksana, N. (2013) "Penentuan kawasan pertambangan berbasis sektor komoditas unggulan sumberdaya nikel Kabupaten Konawe dan Konawe Utara, Provinsi Sulawesi Tenggara," Buletin Sumber Daya Geologi, 8(2), hal. 4153. Tersedia pada: http://buletinsdg.geologi.esdm.go.id/index.ph p/bsdg/article/view/79.

O’Driscoll, B. dan González-Jiménez, J. M. (2016) "Petrogenesis of the platinum-group minerals," Reviews in Mineralogy and Geochemistry, 81(1), hal. 489-578. doi: 10.2138/rmg.2016.81.09.

Okrugin, A. V. (2011) "Origin of platinum-group minerals in mafic and ultramafic rocks: From dispersed elements to nuggets," The Canadian Mineralogist, 49(6), hal. 13971412. doi: 10.3749/canmin.49.6.1397.

Pattnaik, B. K. dan Equeenuddin, S. M. (2016) "Potentially toxic metal contamination and enzyme activities in soil around chromite mines at Sukinda Ultramafic Complex, India," Journal of Geochemical Exploration, 168, hal. 127-136. doi: 10.1016/j.gexplo.2016.06.011.

Rusmana, E., Sukido, Sukarna, D., Haryono, E. dan Simandjuntak, T. O. (1993) "Geologi lembar Lasusua-Kendari, Sulawesi." Bandung: Pusat Penelitian dan Pengembangan Geologi, hal. 2112, 2212.

Singh, P. K. dan Khan, M. S. (2017) "Geochemistry of palaeoproterozoic rocks of aravalli supergroup: Implications for weathering history and depositional sequence," International Journal of Geosciences, 08(10), hal. 12781299. doi: 10.4236/ijg.2017.810074.

Suárez, S., Prichard, H. M., Velasco, F., Fisher, P. C. dan McDonald, I. (2010) "Alteration of platinum-group minerals and dispersion of platinum-group elements during progressive weathering of the Aguablanca Ni-Cu deposit, SW Spain," Mineralium Deposita, 45(4), hal. 331-350. doi: 10.1007/s00126-009-0275-x.

Taboada, T., Rodríguez-Lado, L., Ferro-Vázquez, C., Stoops, G. dan Martínez Cortizas, A. (2016) "Chemical weathering in the volcanic soils of Isla Santa Cruz (Galápagos Islands, Ecuador)," Geoderma, 261, hal. 160-168. doi: 10.1016/j.geoderma.2015.07.019.

Le Vaillant, M., Fiorentini, M. L. dan Barnes, S. J. (2016) "Review of lithogeochemical exploration tools for komatiite-hosted $\mathrm{Ni}$-Cu(PGE) deposits," Journal of Geochemical Exploration, 168, hal. 1-19. doi: 10.1016/j.gexplo.2016.05.010.

Wang, Y., Wang, J., Wang, L., Long, L., Liao, Z., Zhang, H. dan Tang, P. (2011) "Problems of PGE metallogenesis related to maficultramafic complexes in North Xinjiang, China," Geoscience Frontiers, 2(2), hal. 187198. doi: 10.1016/j.gsf.2011.03.008.

Xing, L., Zhou, M., Qi, L. dan Huang, Z. (2015) "Discussion on the PGE anomalies and source materials of K-bentonite (Bed 5) in the Lower Cambrian Meishucun section, Yunnan," Chinese Journal of Geochemistry, 34(3), hal. 346-361. doi: 10.1007/s11631015-0057-3. 